\title{
FREUDIANA: THE LAST CHAPTER
}

\section{Szerző:}

Simó Ferenc Zoltán (Dr. Jur.)

Debreceni Egyetem

Szerző e-mail címe: simofredz@gmail.com

\section{Lektorok:}

Mező Ferenc (PhD)

Eszterházy Károly Egyetem

Kelemen Lajos (PhD)

Okoskocka Kft.

...és további két anonim lektor

\section{Absztrakt}

FREUDIANA: AZ UTOLSÓ FEJEZET

Mint a harmadik és (feltételezhetően) az utolsó része a Freudiana trilógiának, a célunk nem változott. Megpróbáltunk válaszokat találni arra a kérdésre, hogy elhelyezhetô-e a Freudiana a kortárs kultúrában és tudományban. Továbbá, vizsgáljuk azt is, hogy Freudiana és diszkurzív gyakorlata hogyan találja meg saját terét különböző diszciplínákban, még akkor is, ha már számtalanszor visszautasították tanait.

Kulcsszavak: Freud, pszichoanalízis, kultúra, irodalom, populáris kultúra

Diszciplína: pszichológia, kultúra tudomány, irodalomtudomány

\section{Abstract}

As the third and (supposedly) ultimate part of the Freudiana trilogy, our aim has not changed. We have intended to find answers to our question: is there a place of Freudiana in contemporary culture and in science? Also, we examine how Freudiana and its particular discursive practice have found its voice in different disciplines, even if as a science has been rejected countless times.

Keywords: Freud, psychoanalysis, culture, literature, popular culture

Disciplines: psychology, cultural science, literary studies

Simó, Ferenc Zoltán (2021): Freudiana: the Last Chapter. OxIPO - interdiszciplináris tudományos folyóirat, 2021/3, 27-35. doi: 10.35405/OXIPO.2021.3.27 
This is the third and final part of the trilogy, concerning Freudiana without the claim of being either pro or against the Freudian oeuvre, though we agree with those voices who claim that his opus must not be forgotten for one or other reasons, we have met in both first and the second part of this trilogy (Simó, 2020, 2021). There is no doubt about the mere fact that the importance of Freudiana can be and is often questioned by many scholars, who resent the survival of the last bit of the Freudian heritage as well. Their point of view is frequently reasoned and seasoned by simply stating that Freudian theories cannot be proven scientifically or they are all outdated, thus, Freudiana should be forgotten or neglected by scholars, though it is also true that there are some attempts to revive the scientific value of Freudiana as well (see, for example, Akhtar et al, 2009). We do not wish to argue with these researchers, scholars, philosophers and so on, though we intend to show that Freudiana lives on with or without the consent of those feel the need to put all the works by Freud on the shelves to be forgotten forever. Also, to present some cases, which might prove us that the heritage of Freud is still active, at least, culturally (see, for instance, Brooks and Woloch, 2000), by influencing thinkers, for example, in Argentina (Plotkin., 2001), in Africa (its literature and culture) (Ahad, 2010) or, more surprisingly, in the Far
East (Akhtar, 2009). Put it differently, we intend to answer a simple question:

Is there a place of Freudiana in contemporary culture and in science?

\section{Freud and culture(s): \\ endless debates with unlimited number of conclusions.}

One of the well-known topics Freud was fascinated by is culture, which led to the development of his own socioanthropology. His ideas are thought provoking and revolutionary (as his theory of the mind), and it must be admitted that they are the most debated ones.

Eric Smadja examines the representations of society and culture that Freud visualized in the course of his work. Freud's profound interest in these areas led to his creation of a personal socioanthropology, one which was and is criticized excessively by the social sciences of the day as it was supposed to challenge several contemporary sociological and anthropological notions (Smadja, 2015). Freud's view of culture and society embraces both his Viennese and wider Western society and civilization and also historical and so-called „primitive” societies, which he regards from the evolutionist perspective of the 
British anthropologists of his time. It is necessary to realize that when Freud writes about society, culture, civilization, the masses, or the community, it looks vital to take into consideration the relationship and their interrelatedness between these numerous perspectives, both contemporary Viennese and Western, historical and primitive. The hard work is done by Eric Smadja, who explores the complexity of the above mentioned relationship(s), and also provides us a many fascinating questions (with convincing ideas), for example (Smadja, 2015):

What constitutes a culture?

What are its essential traits, its functions, its relationships with society and with nature, and with other aspects of "reality" or of the "external world"?

What account of it did Freud seek to reconstruct, and what role does it play in the development of each individual (ontogenesis) through the construction and functioning of his or her psyche?

His book offers its readers some enthralling answers and elaborates deftly on the characteristically Freudian notion of „Kulturarbeit”, a notion that play a crucial role in Freud's work but which, rather strangely, he never defined. Eric Smadja attempts to reconstruct (and modernise) this concept from a rigorously Freudian perspective by using both his socio-anthropological writings and also those of others outside the field. In addition, he also gives us an elaborate explanation to defend the uniqueness of "Freudian thoughts," he argues that "[a]s for the Freudian notion of Kulturarbeit, it runs through all of Freud's work, from the Interpretation of Dreams on, even if it is not often designated as such. As I have identified it, this notion expresses the existence of relationships of interdependency and interpenetration between socio-cultural and psychic and bodily individual realities. And the originality of Freudian thought is to have indicated to us the diverse modes of leaving its imprint and of individual transmission, bodily as well as intrapsychic, of what is cultural and social, as well as signifying to us that this introjection of social aspects and of culture conditions the constitution of a differentiated psychic apparatus, therefore, the psychic hominisation of every individual that would permit his or her socialisation, therefore, his or her incorporation into society, conferring upon him or her the status of "person« or of »subject«" (Smadja, 2015, 168.).

Abraham Drassinower also states that "Freud's theory of culture positions itself between the demands for action and the claims of a truly human wisdom. It lays bare the dynamics whereby, in refusing the ontological predicaments of loss and death, we deliver ourselves over to the ravages of a history both distant from life and intent upon destroying it, and (...) he also argues that "(...) what is generally (mis)taken as Freud's pessimism is, on the contrary, the very standpoint from which 
he envisions an alternative to the cultural 'malaise' he describes. Freud's theory of culture is a deeply critical theory about how human beings fall short of who they can be by refusing to be the mortal beings that they are. To mistake Freud's attentiveness to loss and death is therefore to forgo the opportunity to develop a language of critique that, neither optimistic nor pessimistic, opposes to things as they are the lessons, in Northrop Frye's phrase, of an 'educated imagination' " (Drassinower, 2003, 1). He adds as well that contrary to predominant images drawn by Freud as a principally psychological thinker, Drassinower displays a deep affinity between Freud's theory of culture and the Western tradition of political philosophy.

\section{Freudiana: lasting influence on different cultures}

Mariano Ben Plotkin argues that it is a captivating history of how psychoanalysis has become an indispensable and crucial element of contemporary Argentine culture, represented in the media, in politics, and even in the private lives of people. He attempts to reveal the unique circumstances, environments and multifaceted historical processes that has already made possible the dissemination, reception, and popularization of psychoanalysis in Argentina, which, he states has the highest number of psychoanalysts per capita in the world. In addition, he also presents us why the intellectual course of the psychoanalytic movement appears different in Argentina than in either the United States or Europe and how Argentine culture both nurtured and shaped by its overarching influence (Plotkin, 2001). In his introduction, he claims that "(o)ne of the things that foreign visitors to any major city in Argentina find most surprising is the enormous presence of psychoanalysis in the urban culture. With four analytic societies affiliated with the International Psychoanalytic Association (IPA) and twenty-nine IPA-affiliated analysts per million inhabitants, Argentina today has one of the highest incidences of Freudian analysts in the world. Argentina also vies with France for first place in the number of Lacanian analysts, those who follow the doctrines of Jacques Lacan. Moreover, in 1995 almost two of every 400 portenos, as the citizens of Buenos Aires are called, were psychologists". (Plotkin, 2003, 2. - See also: Fink, 1999, or Cho, 2009).

In addition, he can even go further by revealing us that " $(. .$.$) in 1995$ almost two of every 400 portenos, as the citizens of Buenos Aires are called, were psychologists, and if they were practicing, they were probably using some kind of psychoanalytically inspired therapy. From politicians to bank clerks, from soap opera stars to cab drivers, and even a few generals - everybody seems to use psychoanalytic language to express the 
concerns of everyday life" (Plotkin, 2003, 1.). When one attempts to measure the fathom of the influence of a well-known, even popular author, he or she has an "easy" job by looking for the presence of the distinctive language or discourse (if there is any) provided uniquely by that particular author.

As we can see, according to Plotkin, the use of the so-called Freudian psychoanalytic language can be identified without difficulties since it has been present and visible all through Argentina and represented by all walks of life. And, it can also be said that this unique situation in Argentina has had a lasing (cultural) effect on Spain and Latin America (including Brasilia, Uruguay and Mexico) as well. Another scholar, Badia Sahar Ahad, in his work Freud Upside Down: African American Literature and Psychoanalytic Culture, presents us a challenging cultural history, an exploration on the way how psychoanalytic theories could shape the works of key African American literary figures, by implication shaping American culture. His detailed analysis shows us how Nella Larsen, Richard Wright, Jean Toomer, Ralph Ellison, Adrienne Kennedy, and Danzy Senna use psychoanalytic terms and theoretical (and abstract) representations to contest and defy notions, including race and racism in twentieth-century America. Moreover, he points out that there is a relationship between these authors and intellectuals and the psychoanalytic movement emerging and evolving in the United States over the twentieth century.

Studying how psychoanalysis has functioned as a cultural phenomenon within African American literary intellectual communities since the 1920s, Ahad outlines the historiography of the nodes between African American literature and psychoanalysis, and even of their personal lives (Ahad, 2010). She also argues that "(...) throughout the course of the twentieth century, black subjects persistently engaged with psychoanalytic thought that has been integral to the working out and working through matters of race, gender, and sexuality" (Ahad, 2010, 156.). We may ponder upon the idea that these complicated issues, such as race, gender and sexuality, are still with us, with no real hope to be "worked out", at least not entirely for the benefit of all. Though our statement may not lessen the merit of Freudiana in African American thoughts and works, on the contrary, it appears to suggest that the scientific refusal of Freudiana does not seem to have had an effect on its cultural relevance.

Also, Ahad goes on to highlight that "(r)ecent appropriations of psychoanalytic thought in black texts, as demonstrated in Danzy Senna's Caucasia, are intimately bound to the formation of race yet are not entirely explicit about the origins of their inspiration. Much like the way in which psychoanalytic language has become part and parcel of the con- 
temporary American vernacular, its presence in African American literature has taken on a more diffuse quality" (Ahad, 2010, 158-159.).

As we can see, according to Badia Sahar Ahad, the origin of the "actual" influence of the Freudiana cannot be traced back to it, at least not clearly, still the psychoanalytic discourse can be found influential. Although she supposes that the challenging part may come when psychoanalytic views and consideration may be applied to more "raced" texts due to a stronger factor of mistrust.

Yet, several critical pieces recognize the presence of psychoanalytic paradigms or patterns in African American novels and short stories as well, the common resistance and conflict to psychoanalysis has created a serious gap in the historical and cultural relationship between African American literary and psychoanalytic communities, even if psychoanalytic tradition is still present and very much alive in America as we have already seen (see, for instance, Net1 or Rustin, 2001).

Claudia Tate states that numerous critics persist to be unconvinced (and even cynical) about psychoanalysis as a critical lens through which to attempt to study black experience. Such uncertainty is mainly owing to the belief (or misbelief) that "the imposition of psychoanalytic theory on African American literature advances Western hegemony over the cultural production of black Americans, indeed over black subjectivity" (Tate,
1998, 192.). We do not intend to argue that any parties above have less "merit" or "value" as far as their critical approaches are concerned, we simply state again that the critical debate, whether it is worthy or not, can create the "reason" or the "ground" for Freudiana to live on.

One of the most fascinating examples of cultural influence can be found in Freud and the Far East: Psychoanalytic Perspectives on the People and Culture of China, Japan, and Korea, edited by Salman Akhtar, whose "mission" can be seen burdened with the twofold aims of bridging the West and East and improving psychoanalytic (re)conceptualization in the way of such a happenstance. Illustrious psychoanalysts from East and West give scrupulous and detailed historical accounts of the progress and expansion of psychoanalysis in Japan, Korea, and China and present their readers with remarkable personages, cultural nuances, founding of journals, and advent of groups interested in psychoanalysis.

Keigo Okinogi argues that the reason for the appearance of Freudiana is mainly historically rooted since, he claims that Japanese culture and psychoanalysis have two visible periods, namely, "(t)he history of psychoanalysis in Japan may be roughly divided into two periods: (1) the period before World War II and (2) the period from the end of World War II to the present" (Okinogi, 2009, 9.) also, he states that "( $\mathrm{t}$ )he first Japanese document on 
psychoanalysis, an article by Kaison Ohtsuki titled 'The Psychology of Forgetfulness' appeared in a journal of psychological research in 1912. The same year, Kyuichi Kimura published 'How to Detect the Secrets of the Mind and to Discover Repression' which introduced psychoanalysis as a scientific method of exploring people's thoughts." (Okinogi, 2009, 9.). He names the dynamic psychiatry of the United States as the greatest influence, and admits that founding the clinical uses of these theories has already turned out to be a major task (or even a test) for many Japanese clinicians, which may due to cultural differences as well, and the differences in Japan and Western mentality. Still, Okinogi stays optimistic, since "( $\mathrm{t}$ )he number of patients receiving psychoanalytic psychotherapy has increased dramatically in the Japanese cities of Tokyo, Osaka, Fukuoka, Kobe, and Hiroshima. There has also been a sharp rise in the number of private psychotherapeutic clinics operating in Tokyo, including five or six psychoanalytic psychotherapy clinics. These trends indicate potential for the future growth of psychoanalysis and psychoanalytic psychotherapy in Japan" (Okinogi, 2009, 25.).

One might be concerned by the fact that, as we have already summed up in the first two part in the trilogy, the scientific value of Freudiana has been shaken, still its language and its special discourse can prevail through, for example, the eyes of the Far East.

In Korea, for instance, the reception and the development of Freudiana may be seen differently, Do-Un Jeong and David Sachs argue that "Asia, in general, has no international access to psychoanalytic training and education except in domestic Japan and India. So psychoanalytic development in Asian countries should be quite different from what has been occurring for the past years in Eastern European countries. Koreans have had no possibility of condensed analysis, shuttle analysis, and other choices. Unlike European languages, Korean, Japanese, and Chinese share very little linguistically" (Do-Un Jeong and David Sachs, 2009, 30.).

Cultural and historical differences may be the source(s) of the late influence of Freudiana in Korea, but the promising future of psychoanalysis looks to have been settled. They also conclude (and hope) that "(K)orea is now an emerging young power of the psychoanalytic movement in Asia. It has been a very slow process since the foundation of the Seoul Psychoanalytic Study Group in 1980, filled with expectations, frustrations, internal turmoil, sense of achievement, and pride. We think the Korean experience can be referred to and shared for new countries now and in the future for the timely and sustainable development of psychoanalysis and the 
release from the divide worldwide" (DoUn Jeong and David Sachs, 2009, 40-41.). As we can see the rediscovery of the Freudian heritage has already begun even if the so-called scientific validity of Freudiana might have been questioned, erased or eroded by time. Now the Far East has it say in this matter (to get to know more about this topic, see, for instance: Psychoanalysis in China by Douglas Kirsner and Elise Snyder, 2009).

\section{Conclusion}

As the third, English part of the Freudiana trilogy, we have decided to show some morsels of the attention paid by scholars to Freudiana, with our intention to answer a simple question whether there might be a place for Freudiana in contemporary culture and in science. This task has never been and will not be an easy one, since the great number of studies on the Freudian oeuvre has its advantages and disadvantages, what to include and what to neglect can be burdensome, but our task has had only one focus: to prove, or at least, attempt to prove that Freudiana has not been forgotten, on the contrary, we may see its Renaissance again in the Far East. Also its reconciliation or compromise with religion, but this topic might be examined by a fourth study.

\section{References}

Ahad, B. S. (2010): Freud Upside Down: African American Literature and
Psychoanalytic Culture. Illinois:

University of Illinois Press, Akhtar, S., Cai, J., Choi-Kain, L., Chu, J.,

Freeman, D., Gu, M.D., Do-Un

Jeong, D-U., Kim, M., Kirsner, D.,

Kitayama, O., Kosawa, H., Moore, M.,

Nayar, M., Okinogi, K., Roland, A.,

Sachs, D., Snyder, E., Taketomo, Y.,

Twemlow S., van Waning, A. (2009):

Freud and the Far East: Psychoanalytic

Perspectives on the People and Culture of

China, Japan, and Korea. New York:

Jason Aronson, Inc.

Brooks, P. and Woloch, A. (2000): Whose

Freud?: The Place of Psychoanalysis in

Contemporary Culture. Yale: Yale

University Press.

Cho, K. D. (2009): Psychopedagogy: Freud,

Lacan, and the Psychoanalytic Theory of

Education (Education, Psychoanalysis,

Social Transformation). New York:

Palgrave Macmillan,

Douglas, K. and Snyder, E. (2009).

Psychoanalysis in China. In: Akhtar, S.

(Ed.): Freud and the Far East:

Psychoanalytic Perspectives on the People and

Culture of China, Japan, and Korea. New

York: Jason Aronson, Inc.

Do-Un. J. and David Sachs, D. (2009).

Psychoanalysis in Korea, In: Akhtar, S.

(Ed.): Freud and the Far East:

Psychoanalytic Perspectives on the People and

Culture of China, Japan, and Korea. New

York: Jason Aronson, Inc.

Drassinower, A. (2003): Freud's Theory of

Culture: Eros, Loss, and Politics. New 
York: Rowman and Littlefield

Publishers, INC.

Fink, B. (1999): A Clinical Introduction to

Lacanian Psychoanalysis: Theory and

Technique. Cambridge: Harvard

University Press

Net1: "Psychoanalysis and the Public Sphere:

Social Fault Lines". Downloaded:

01.09.2021. Web:

https://www.freud.org.uk/event/psyc

ho analysis-and-the-public-sphere-

socialfault-lines/

Okinogi, K. (2009): Psychoanalysis in Japan. In: Akhtar, S. (Ed.): Freud and the Far East: Psychoanalytic Perspectives on the People and Culture of China, Japan, and Korea. New York: Jason Aronson, Inc.

Plotkin, M. B. (2001): Freud in the Pampas:

The Emergence and Development of a

Psychoanalytic Culture in Argentina.

Stanford: Stanford University Press.
Rustin, M. (2001): Reason and Unreason: Psychoanalysis, Science and Politics. London: Continuum Books.

Simó F. Z. (2020): Freudiana. OxIPO interdiszcciplináris tudományos folyóirat, 2020/4, 59-68. doi: 10.35405/OXIPO.2020.4.59

Simó F. Z. (2021): Freudiana: az örökség tovább él. OxIPO - interdiszciplináris tudományos folyóirat, 2021/2, 77-85. doi: 10.35405/OXIPO.2021.2.77

Smadja, E. (2015): Freud and Culture. Psychoanalytic Ideas and Applications. London: Karnac Books

Tate, C. (1993): Domestic Allegories of Political Desire: The Black Heroine's Text at the Turn of Century. New York: Oxford University Press.

Tate, C. (1998): Psychoanalysis and Black Novels: Desire and the Protocols of Race. New York: Oxford University Press. 